\title{
Adjustment of TV viewing: Adolescents in relation to their family structure
}

- Dr. Sanjeev Tomar

\section{Introduction}

Originally, the word adjustment is derived from the concept of adaptation in biology. Adaptation refers to the biological changes that facilitate the survival of any species. From psychological point of view, adjustment means individuals' struggle to survive in their surroundings and achieve a harmonious relationship with the environment. The relationship refers to environment involving the ability to satisfy most of one's needs and meets. Palsane (1977) has stated "Adjustment meant the relationship between individual and his environment." It indicates how well a particular individual has been able to cope up with the environment around.

Adolescence is considered most critical period in human development because this period starts transforming individual from dependence to independence. Viewing TV at this period affects their physical, mental, moral, spiritual, curiosity and social outlook. Himmelweit, Oppenheim and Vince (1958) observed that television viewers were more curious about the world and showed a wider variety of interests than the nonviewers. Straburger and Wilson (2002) reported that children's TV viewing habits change remarkably as they become adolescents. Studies have also spoken that the adolescents' TV viewing concerns parents, teachers and mental health professionals in India also (Kalia, 2003; Suriakanthi and Meenakshi, 1989). Family structure is agreed to play its role in the adjustment of the adolescents and personality make-up. Lyle and Parker (1961) found that children who had unsatisfactory relationships with their families and / or with their peer groups tended to retreat from those social interactions 
into television viewing. They do so because the escape could leave real life problem behind them at least for a short time and possibly reduce tension in their lives.

Hardly any disagreement exists over the fact that TV viewing has changed the values of human beings, their thinking ways, time schedules and living style. Thomas and Tiwari (1986), Narayana (1987), Joshi and Laharia (1992), Rao (1992), Tiwari, Singh and Rath (1997) found that viewing TV programmes influenced the social life and adjustment of both urban and rural. Similarly, Chopra (1990), Ananthasayanam, Prama and Vidhya (1992) reported the impact of TV viewing on their knowledge, attitude and awareness of rural and urban people.

Anuradha and Bharathi (2001) found that television is often blamed by the parents for children's poor academic performance. Several researches have opined that in order to reduce negative effects of television viewing on children, parents should control their children's excessive TV watching (Rajani, 1987; Singer, 1989 and Prawd, 1995). Promila and Dilsheed (2000) found that those parents who punish their children physically and express dissatisfaction with their children's accomplishments and characteristics are responsible for their children's preference to TV watching. Since their relations with parents are unsatisfactory, they spend more time in watching TV (Eron, 1982). Researchers have reported that the modern families have become less able to socialize children effectively because of reduced parental authority, and less able to provide care, affection and companionship. Dorr and Rabin (1995) found that those children who spend several hours watching television no matter what the content being telecast are less social. There were fairly good evidences that greater amounts of viewing were associated with less satisfactory social relationship, fewer inter personal interactions, lower reading skills, lower schools achievement and fatter bodies.

\section{Objective}

This research endeavours to explore the effects of differential amount of TV viewing on the adjustment of school going 
adolescents in relation to their gender and family structure.

\section{Hypotheses}

The following hypotheses were formulated:

1. No significant difference exists in the adjustment of light and heavy TV viewers dimension wise.

2. No significant difference exists in the adjustment of boys and girls component wise.

3. No significant difference exists in the adjustment of nuclear and joint family-children dimension-wise.

4. Duration of TV $x$ Gender will not affect adjustment dimension wise.

5. Gender x Family structure will not affect adjustment dimension wise.

6. Duration of TV $x$ Family structure will not affect adjustment dimension wise.

7. Effects of Duration of TV viewing x Gender x Family structure will not exist in the set.

\section{Method}

The details of the methodology and procedure adopted during the study are as follows:

Research design: A 2x2x2 Ex-Post facto non-experimental factorial design consisting of three independent variables viz duration of TV viewing, gender and family structure was employed. Duration of TV viewing was varied at two levelslight TV viewers and heavy TV viewers. The extreme grouping of light and heavy TV viewers was decided by applying the formula $\mathrm{M}+\mathrm{SD}$. Gender and family structure were naturally dichotomous variables i.e. Gender-boys and girls, Family structure- nuclear family and joint family.

Sample: As per the need of $2 \times 2 \times 2$ factorial design, the stratified random sampling technique was applied. The respondents chosen for the study ranged from 16 to 18 yrs old $(\mathrm{M}=16.5)$ and belonged to the families of middle socio-economic status. In 
first instance, 848 respondents were chosen for the study; but finally, 680 respondents (85 in each cell) were selected according to the set paradigm from 19 Indian Government aided schools of Meerut district (U.P.) India. See figure 1 below:

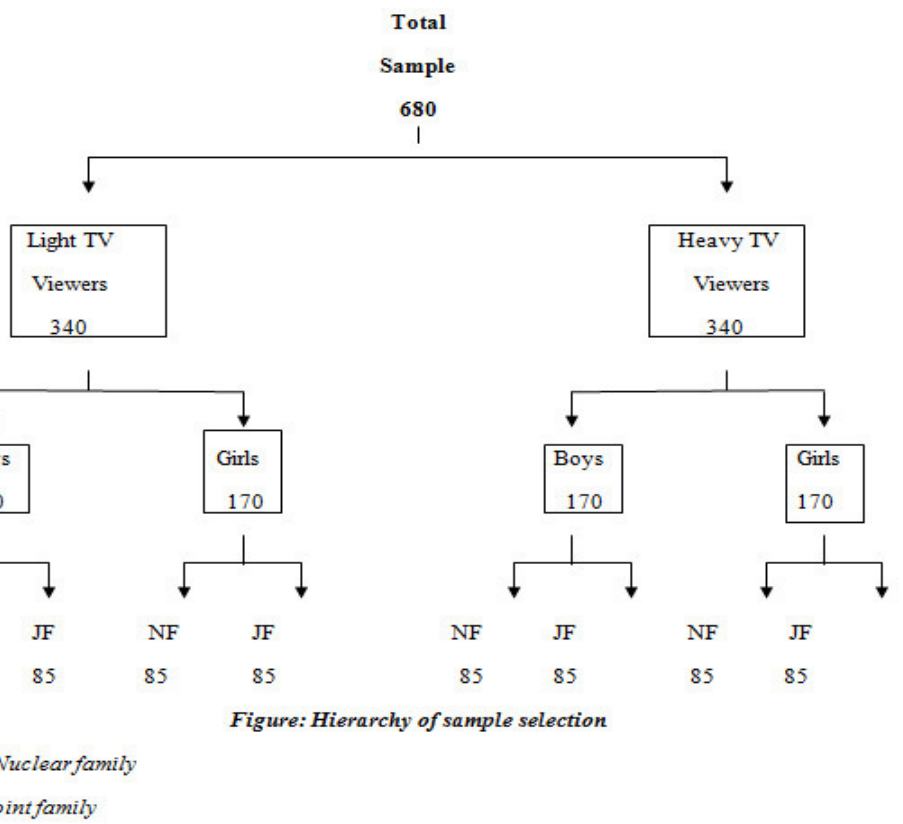

Figure 1: Hierarchy of sample selection

Dependent variable: Adjustment

Independent variable: TV Viewing, Gender and Family Structure

\section{Operational definitions}

TV viewing: Those children who watched TV for less than $2 \mathrm{hrs}$ and 45minutes daily were labeled as light TV viewers; while those who were used to watching television more than $2 \mathrm{hrs}$ and 45 minutes perday were considered as heavy TV viewers.

Family structure: It pinpoints a visible difference in the children of nuclear and joint family population in India. 
Difference in family structure can easily be observed in the parents'control over the children, their belief, mode of living, customs, family interaction and material possession etc. This difference in the present endeavour was termed as family structure having two dimensions-nuclear level and joint level.

Adjustment: The adjustment in children viz home, social, health and school refers to the relationship between individual and his surroundings. Home adjustment refers to the relationship between family members; social adjustment- adaptability to social environment i.e.brotherhood, honesty, co-operation etc.; health and emotional adjustment -- child's physical and emotional development in conformity with others of his age group.

School adjustment: How far a child feels self-satisfied with his school regarding his academic performance, relation with his friends and teachers. Total adjustment indicates the overall adjustment of child in above mentioned four areas.

\section{Tools}

Adjustment inventory: The inventory developed by Mittal, V.K. (2006) was employed to measure the adjustment in four areas namely home, social, health and school. Split-half reliability (odd-even method) was used and Spearman-Brown's correction was found to be .94 for the total scale. The reliability coefficient in four areas ranged from .44 to .80 . The inventory was validated against two external criteria and validity co-efficient ranges from .597 to .693 .

Student information blank: It was employed to find out the demographic, parental and personal characteristics of students.

Procedure: The student information blank and adjustment inventory both were administered in group setting as per the instructions mentioned in the manual. The collected raw data was scored as per the manual, i.e., scoring of the adjustment in the inventory is simple. Every category of response was given 
score. Maximum score to be given on an item was 3. This was indicated by coloured hole on the scoring stencil, doubtful response was always to be scored as 2 and the score on the rest of the item was 1 . There were separate scoring stencils for each page area-wise. Adding all the scores obtained for a particular sub-scale; then total score was recorded, so obtained, on the cover page of the inventory. The total score obtained for all the pages indicated overall adjustment score.The raw data was treated for statistical analysis by calculating mean, standard deviation and three-way ANOVA.

\section{Results}

In order to examine the difference in adjustment among light and heavy TV viewers, boys and girls; and children of nuclear and joint family, the raw data collected was analysed by using mean, standard deviation and three way ANOVA $(2 \times 2 \times 2$ factorial design).

The result (Table 1) on adjustment of light TV viewers and heavy TV viewers do not differ significantly at any areas as shown in Table 1.

$\underline{\text { Table } 1}$

Mean, Standard Deviations and F-ratios of Light and Heavy TV viewers on Sub-scales of Adjustment $(N=680)$

\begin{tabular}{|c|c|c|c|c|c|}
\hline \multirow{2}{*}{$\begin{array}{l}\text { Subscales } \\
\text { of } \\
\text { Adjustment }\end{array}$} & \multicolumn{2}{|c|}{$\begin{array}{l}\text { Light TV viewers } \\
\qquad(\mathrm{n}=340)\end{array}$} & \multicolumn{2}{|c|}{$\begin{array}{l}\text { Heavy TV viewers } \\
\qquad(\mathrm{n}=340)\end{array}$} & \multirow[b]{2}{*}{$\mathrm{F}$} \\
\hline & $\mathrm{M}$ & SD & $\mathrm{M}$ & SD & \\
\hline $\begin{array}{l}\text { Home } \\
\text { Social } \\
\text { Health } \\
\text { School } \\
\text { Total }\end{array}$ & $\begin{array}{l}47.73 \\
6.79 \\
46.56 \\
5.99 \\
45.96 \\
6.78 \\
44.83 \\
6.31\end{array}$ & & $\begin{array}{l}48.41 \\
1.82 \\
47.19 \\
2.02 \\
45.38 \\
1.15 \\
45.34 \\
1.03\end{array}$ & $\begin{array}{l}7.38 \\
6.75\end{array}$ & \\
\hline
\end{tabular}




\begin{tabular}{|l|l|ll|}
\hline & 185.07 & 186.32 & 31.00 \\
31.69 & 0.65 & \\
\hline
\end{tabular}

Mean, Standard Deviations and F-ratios of Light and Heavy TV viewers on Sub-scales of Adjustment $(N=680)$ $d f=672$.

On the second independent variable gender, boys and girls significantly differed in the areas of home $(\mathrm{F}=4.30, \mathrm{P}<.05)$, social $(\mathrm{F}=11.86, \mathrm{P}<.01)$ and health adjustment $(\mathrm{F}=13.93, \mathrm{P}$ $<.01)$.

The mean scores indicate that girls are higher on home and social adjustment as compared to boys, whereas boys are found to be higher on health adjustment as compared to girls (Table 2).

Table 2

Mean, Standard Deviations and ' $F$ ' ratios of Boys and Girls on Subscales of Adjustment

$(N=680)$

\begin{tabular}{|c|c|c|c|c|c|}
\hline \multirow{2}{*}{$\begin{array}{c}\text { Subscales } \\
\text { of } \\
\text { Adjustment }\end{array}$} & \multicolumn{2}{|c|}{$\begin{array}{c}\text { Boys } \\
(\mathrm{n}=340)\end{array}$} & \multicolumn{2}{|c|}{$\begin{array}{l}\text { Girls } \\
(\mathrm{n}=340)\end{array}$} & \multirow[b]{2}{*}{$\mathrm{F}$} \\
\hline & M & SD & M & SD & \\
\hline \multirow{10}{*}{$\begin{array}{l}\text { Home } \\
\text { Social } \\
\text { Health } \\
\text { School } \\
\text { Total }\end{array}$} & 47.54 & & 48.59 & 7.01 & \\
\hline & 6.07 & & $4.30 *$ & & \\
\hline & 46.11 & & 47.64 & 5.82 & \\
\hline & 5.76 & & $11.86^{* * *}$ & & \\
\hline & 46.67 & & 44.67 & 7.05 & \\
\hline & 6.99 & & $13.93 * *$ & & \\
\hline & 44.78 & & 45.39 & 6.40 & 1.48 \\
\hline & 6.66 & & 186.29 & 20.33 & 0.58 \\
\hline & 185.10 & & & & \\
\hline & 19.90 & & & & \\
\hline
\end{tabular}

$$
\mathrm{df}=672 . * \mathrm{P}<.05, * * \mathrm{P}<.01
$$


On the third independent variable - family structure - no significant difference was observed in area of the adjustment between the children of nuclear family and joint family. (Table 3)

Table 3

Mean, Standard Deviations and F-ratios of Nuclear and Joint Family on Subscales of Adjustment $(N=680)$

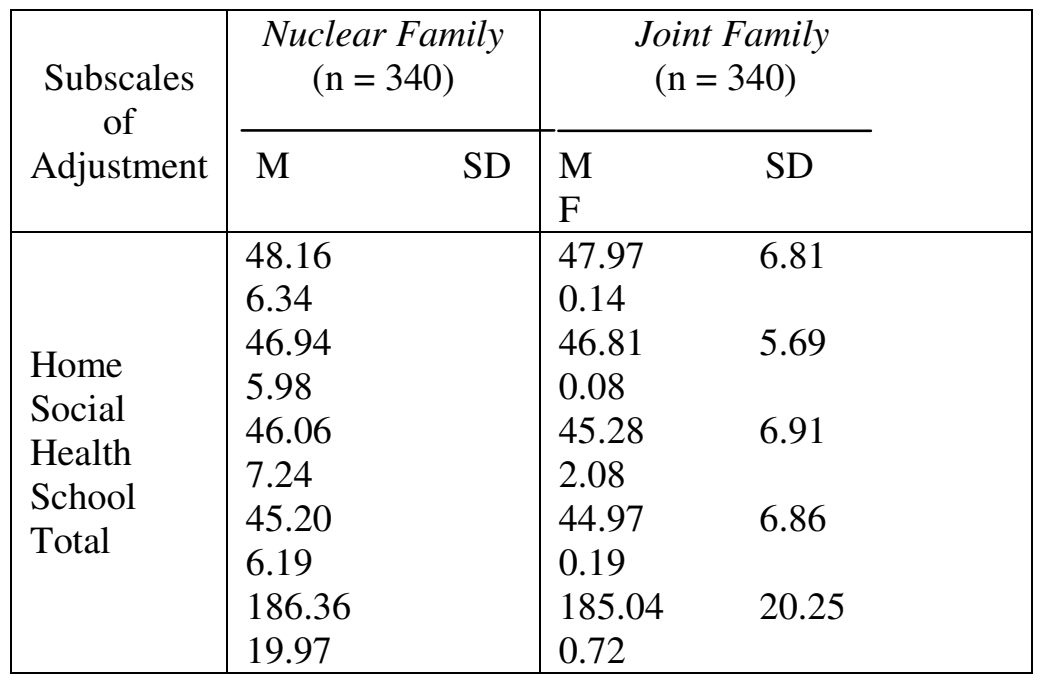

$$
\mathrm{df}=672 \text {. }
$$

Table 4

Interactional Effects of TV viewing (A); Gender (B) and Structure of Family $(C)$ on Subscales of Adjustment $(N=680)$

\begin{tabular}{|l|c|c|c|c|}
\hline $\begin{array}{l}\text { Subscales of } \\
\text { Adjustment }\end{array}$ & A x B & B x C & A x C & A x B x C \\
\hline Home & 0.27 & 1.58 & 0.11 & 2.34 \\
Social & 2.02 & 1.11 & 0.01 & 3.56 \\
Health & 5.43 & 0.28 & 1.55 & $8.61^{* *}$ \\
School & 0.00 & 0.51 & 2.84 & 3.47 \\
Total & 1.93 & 0.105 & 0.03 & 2.07 \\
\hline \multicolumn{4}{|c|}{ df $=672, \mathrm{P}<.01$}
\end{tabular}




\section{Discussion}

The primary purpose of the present attempt was to compare light and heavy TV viewers' adjustment. The result of the study indicates that there is no significant difference between light and heavy TV viewers on their adjustment (Table 1). The probable reason can be the help from parents of both types' families to their children in their adjustment with themselves or with the surrounding environments. This leads to a conclusion that the duration of TV viewing does not affect the adjustment of TV viewing children if they are allowed to watch wisely selected programmes under parents' supervision. Peterson, Peterson and Carroll (1986), Rajani (1987), Singer (1989) and Prawd (1995) support the existing finding. They reported that in order to reduce negative effects of TV viewing on children, parents should control their children's excessive TV viewing habit.

Another prominent purpose of the study was to compare the adjustment between boys and girls dimensionwise. Girls were found to be higher on home and social adjustment as compared to boys; while boys were found to be higher on health adjustment as compared to girls. The probable reason may be that girls are very soft natured and thus they talk in very sweet and polite way. These qualities help them make friends whether they (people) are their family member or neighbours. The boys, on the other hand, are found to be high on health adjustment. The probable reason may be that boys at the age of adolescence want to show themselves like He-man or body builders so as to impress their classmate especially girls. Malina (1996) has also reported that significant difference in physical activity patterns among adolescent children with respect to their gender existed. Kalia and Tomar (2003) reported that male adolescents TV viewers were significantly more adjusted on health adjustment in comparision to female TV viewing adolescents.

The third purpose of the study was to compare children from nuclear with joint families. Table 3 reveals that there is no 
significant difference between children from nuclear and joint family at any significant level in the adjustment. The probable reason may be that the children from both types of families are given near about same liberty and facilities. That is why the children of both types of families feel equal adjustment with their family, peers and the surroundings.

On the two way interaction $\mathrm{AxB}, \mathrm{BxC}$ and $\mathrm{AxC}$; no significant difference was noticed among the children on their adjustment. While on the triple interaction $(\mathrm{AxBxC})$ significant difference was observed in the health adjustment. The probable reason may be high significant $\mathrm{F}$ ratio found in the health adjustment between boys and girls. That affected the triple action at large on health adjustment component. On the basis of the findings, it can be concluded that gender affects the adjustment of the children highly but partially. However duration of TV viewing and family structure does not affect the adjustment level of the children significantly. While this effect lays influence on the adjustment of children with the interaction among the triple interaction on the health adjustment. This concludes that these variables exert more impact on health adjustment in combination, thus the effect individually and jointly was observed on health adjustment of the children.

\section{Educational implications}

Educational environment at home and school practice can augment the right approach in the school-going-children belonging to both joint and nuclear families. In teacher-parent meetings, parents should be told that TV viewing does not harm the adjustment of the children if watched prudentially. Singh and Khan (1997) have opined "Tvpreents notonlylife experiences but also presents them more effectively than any other communication media. It educates, informs and entertains. Children are its special audience." So, parents should realize about their duties towards their children in controlling their TV viewing habit. Teachers and principal at morning pray should 
tell all the children the significance of our duties and responsibilities towards our family members and neighbours.

\section{References}

Ananthasayanam, R, Prama, P., and Vidhya, R. (1992). Impact of non-formal educational TV programmes on rural women, Journal of Educational Research and Extension, 29 (2).

Anuradha, K., and Bharathi, V.V. (2001). TV viewing and children's academic achievement with reference to punishment patterns exercised by the parents. Psycholingua, 31 (1), 9-13.

Chopra, R. (1990). Impact of television on social awareness of adults. Indian Journal of Adult Education, 51 (1), 4548 .

Dorr, A., and Rubin, B.T. (1995). Parents, children and television. Handbook of Parents, 4, 223-251.

Exon L. D. (1982). Parent-child interaction, television violence and aggression of children. American Psychologist, 2, 197-221.

Joshi, A., and Gautam, M. (2002). TV viewing patterns of adolescents and its impact on their studies. Psycholingua, 32 (1), 21-26.

Joshi, N. N., and Laharia, S. N. (1992). Farm telecast viewing behaviour of farmers. Indian Journal of Extension Education, 18, (1\&2), 15-22.

Kalia, A. K., and Tomar, S. (2003). Impact of TV viewing on adjustment,values and academic achievement of adolescents in relation to gender. New Horizons, 4 (4), 6-12

Kalia, H. L. (2003). School based approaches of child guidance and counseling services in Mumbai city. Journal of Psychological Researches, 47, 57-60. 
Kaur, J. (1998). Impact of viewing TV on the social life of rural illiterate and neo-literate adults. Psycho-lingua, 28 (1), $39-44$.

Malina, R. M. (1996). Tracking of physical activity and physical fitness across the life span. Research Quaterly for Exercise and Sport, 6, 48-57

Mittal, V. K. (2006). Manual of adjustment inventory, Merut: Manovigyan Kendra.

Narayanan, A. (1987). Impact of TV on viewers: A case study of Bombay TV viewers. Bombay: Somaiya Publications.

Palsane, M. N. (1977). Palsane's adjustment inventory Manual. Pune: Anand Agencies.

Peterson, C, Peterson, J., and Corroll, J. (1986). Television viewing and imaginative problem-solving during preadolescence. Journal of Genetic Psychology, 147, 6667.

Prawd, L. (1995). The negative effect of television on children, International Journal of Instructional Media, 22 (3), 255-261.

Rajani, M. K. (1987). Report of national seminar on Television and child development, 12-14 Feb, New Delhi: NIPCCD.

Rao, B. S. S. (1992). Television for rural development. New Delhi: Concept Publishing Company.

Schrann, W., Lyle, J., and Parker, E.G. (1961). Television in the lives of our children: The early years. In S. Lowery and M. L. Defleur (1983), Milestone of mass communication research: Media effects (pp. 267-295). New York: Longman Inc.

Singer, D.G. (1989). Caution: Television may be hazardous to child's mental health. Journal of Developmental and Behavioral Pediatrics, 10 (6), 320. 
Singh, A., and Kaur, A. (1997). Impact of television programmes on socio-psychological behavior of urban primary school children, Psycho-lingua, 27, 1, 47-52.

Singh, P., and Kaur, D. (2000). A study of parent-childinteraction and parental restrictions on TV viewing among children. Psycho-lingua, 30 (1), 31-36.

Suriakanthi, A., and Meenakshi, D. (1989). Parental views on the usefulness of television programmes to children. Experiments in Education, 17 (7), 174-177.

Taj, H., and Masthan, N. S. (1998). Television: A spurt to modern perspectives of education, Psycho-Lingua, 28 (2), 167-169.

Thomas, A.S. and Tiwari, N. (1986). TV viewing behaviour of urban women, Indian Journal of Adult Education, Vol, 47, No. 5, pp. 19-23.

Tiwari, R.; Singh, R. and Rath (1997). Rupasi farmers' opinion about chaupal- the farm telecast. Indian Journal of Adult Education, 58 (1), 59-62.

The author is Assistant Professor at Department of Education, Shri Varshney (PG) College, Aligarh (U.P.) India Email-sanjeevbrt@rediffmail.com 